Tropical Journal of Pharmaceutical Research February 2017; 16 (2): 327-336

ISSN: $1596-5996$ (print); 1596-9827 (electronic) (c) Pharmacotherapy Group, Faculty of Pharmacy, University of Benin, Benin City, 300001 Nigeria.

All rights reserved.

Available online at http://www.tjpr.org

Original Research Article

http://dx.doi.org/10.4314/tjpr.v16i2.10

\title{
Pharmacological evaluation of novel dimers of an arylpropionic acid class of non-selective cyclooxygenase inhibitors
}

\author{
Syed Muhammad Ashhad Halimi ${ }^{1 *}$, Muhammad Saeed ${ }^{1}$, Safiullah ${ }^{1}$ and Khalid \\ Muhammed Khan ${ }^{2}$
}

${ }^{1}$ Department of Pharmacy, University of Peshawar, Peshawar 25120, ${ }^{2}$ H.E.J. International Centre for Chemical and Biological Sciences (ICCBS), University of Karachi, Karachi 75270, Pakistan

*For correspondence: Email: ahhadhalimi@upesh.edu.pk; Tel: +92 91 9216750; Fax: +92 919218318

\begin{abstract}
Purpose: To explore and identify cyclooxygenase (COX) inhibitors with optimal potency and efficacy using an ary/propionic acid class of drugs as lead molecules.

Methods: The selected lead molecules were dimerised through chemical processes (reflux condensation) and characterised in terms of structural properties using infrared, proton nuclear magnetic resonance, electron impact mass spectrometry, and elemental analysis techniques. The molecules were evaluated pharmacologically for acute toxicity and anti-inflammatory (carrageenaninduced paw oedema test), analgesic (acetic acid-induced writhing test in mice), and antipyretic (Brewer's yeast-induced pyrexia test in mice) activities against control (normal saline) and relevant reference standard drugs. Docking analyses were also performed to assess possible protein-ligand interactions.

Results: The test compounds were non-toxic at doses of 50, 100 and $150 \mathrm{mg} / \mathrm{kg}$ body weight, ip. Pharmacological evaluation revealed that the test compounds, TC-I through TC-IV, had significant antiinflammatory and peripheral analgesic activities $(p<0.001)$. An antipyretic test showed that TC-I, -II, and -III showed highly significant antipyretic activities at all doses tested. TC-IV at 20 and $30 \mathrm{mg} / \mathrm{kg}$ body weight exhibited significant antipyretic activities $(p<0.05)$, while at $50 \mathrm{mg} / \mathrm{kg}$ body weight, the activity was highly significant $(p<0.001)$. Molecular modelling revealed strong inhibitory interactions with docking scores of 116.2, 128.8, 144.2, and $136.0 \mathrm{kcal} / \mathrm{mol}$, respectively, in comparison with the reference ligand, flurbiprofen $(94.9 \mathrm{kcal} / \mathrm{mol})$.

Conclusion: The dimerised lead drug molecules showed significant anti-inflammatory, analgesic, and antipyretic activities in animals and may further be explored as potential new drug candidates for inflammatory conditions.
\end{abstract}

Keywords: Analgesic, Anti-inflammatory, Antipyretic, Arylpropionic acid, COX-2 inhibitors, Molecular docking

Tropical Journal of Pharmaceutical Research is indexed by Science Citation Index (SciSearch), Scopus, International Pharmaceutical Abstract, Chemical Abstracts, Embase, Index Copernicus, EBSCO, African Index Medicus, JournalSeek, Journal Citation Reports/Science Edition, Directory of Open Access Journals (DOAJ), African Journal Online, Bioline International, Open-J-Gate and Pharmacy Abstracts

\section{INTRODUCTION}

Cyclooxygenase (COX) inhibitors, non-steroidal anti-inflammatory drugs (NSAIDs), are commonly prescribed and used for their anti-inflammatory, analgesic, and antipyretic activities. A diverse collection of NSAIDs, such as arylpropionic acids, arylacetic acids, $\beta$-ketoenols, and diary heterocycles, acts by inhibiting the activity of cyclooxygenase (COX) enzymes [1]. NSAID 
selection depends on the clinical condition of the patient under treatment, COX1 and COX2 selectivity, duration of use, and gastric ulcerative and cardiovascular risks [2].

A prolific area of research looks at existing drug molecules that may be further amplified in terms of potency, efficacy, selectivity, or safety. The development and successful testing of molecular computations for both the receptors (proteins) and ligands (drugs) has further aided the efforts of researchers, to the point of designing appropriate drug structures for both known and unknown proteins, receptors, or enzymes [3,4].

Well-established lead NSAID molecules for synthesising derivatives have the advantages of predicable pharmacological activities, known doses, durations of action, and side and toxic effects. The pharmacological evaluation of such synthesised analogues, in vivo and through computer docking, can provide useful data for further augmentation of the existing lead molecule; for more benefits and fewer side effects, the 'better' structure could be screened out among the synthesised analogues for further optimisation of its pharmacological activity. Several success stories have been reported to date regarding such computer-aided drug discoveries [5].

Naproxen [6], flurbiprofen [7], and ibuprofen [8], belonging to the arylpropionic acid class of nonselective COX inhibitors, were selected for synthesis of their dimers and further exploration of these dimers for anti-inflammatory, analgesic, and antipyretic activities. Molecular docking analyses were also performed to assess probable drug-receptor interactions with this new COX inhibitor approach.

\section{EXPERIMENTAL}

\section{Chemicals}

Pharmaceutical-grade ibuprofen, flurbiprofen, and naproxen were provided by Polyfine Chemipharma (Pvt.) Ltd, Hayatabad, Peshawar, Pakistan. Ethanol and concentrated sulphuric acid were obtained from Sigma-Aldrich, USA. Lambda carrageenan (Sigma, USA), glacial acetic acid (Panreac, Spain), Brewer's yeast (Merck, Germany), and sterile normal saline I/V (Otsoka Japan) were used as received.

The purity of the products was checked on thinlayer chromatographic plates of aluminium coated with silica gel (Kieselgel 60 F25, Merck, Germany). Melting points were assessed with a Bicot apparatus (Bibby Scientific Ltd., UK).
Proton nuclear magnetic resonance $\left({ }^{1} \mathrm{H}\right.$ NMR) measurements were performed using a Bruker AV 300 system $(400 \mathrm{MHz})$ with dimethyl sulphoxide (DMSO) as the solvent. Electron impact mass spectroscopy (EI MS) was conducted with a JEOL MS Route spectrometer (JMS 600-H). Infrared (IR) spectra were obtained with a Jasco IR-A-302 spectrometer. Ultraviolet (UV) spectra were generated with a Thermo Electron Vision Pro (ver. 4.10). C:H:N analyses were performed with a Carlo ErbaStrumentazione system (Mod-1106, Italy).

Anti-inflammatory activity tests were conducted using a plethysmometer (Model LE 7500 Plan lab S.L.). Antinociceptive activity was assessed with a hot plate analgesiometer (Havvard Apparatus, USA). Antipyretic activity was measured using a digital thermometer (Model CA92121, ACON Laboratories, USA).

\section{Synthesis}

Ethyl ester analogues of naproxen, flurbiprofen, and ibuprofen were synthesised through reflux condensation of the reactants in an equimolar (0.1 mmol:0.1 mmol) ratio in an acidic environment, with the addition of a few drops of concentrated sulphuric acid to the reaction [9]. Completion of the reaction was monitored using thin layer chromatography (TLC), with ethyl acetate and hexane as the mobile phase. The reaction duration ranged from $12-18 \mathrm{~h}$. The resulting solid products were filtered, washed with hot hexane (200-400 mL) and distilled water (400-500 mL), and then dried (Step 1). Esterified compounds thus synthesised were treated with hydrazine hydrate, and again subjected to reflux condensation for 24-48 $\mathrm{h}$, using ethanol as the solvent [10]. Completion of the reactions was ascertained using TLC. The products were then purified with different techniques (Step 2). The esters and hydrazides thus synthesised were refluxed overnight, in the presence of carbonyldiimidazole (CDI) as the catalyst, using acetonitrile as the reaction medium. General Scheme I shows dimer formation in a three-step reaction. The products formed were then purified similarly through the different techniques.

\section{Experimental animals}

Mice (BALB-C) from the National Institute of Health (NIH) Islamabad, Pakistan, were used for the experimental studies. Mice were fed with standard food ad libitum with free access to drinking water, and kept at $25 \pm 2^{\circ} \mathrm{C}$ with a 12$\mathrm{h} / 12-\mathrm{h}$ day/night cycle. The animal studies were approved by the Ethical Committee of the University of Peshawar, Pakistan (ref no. 01/EC- 

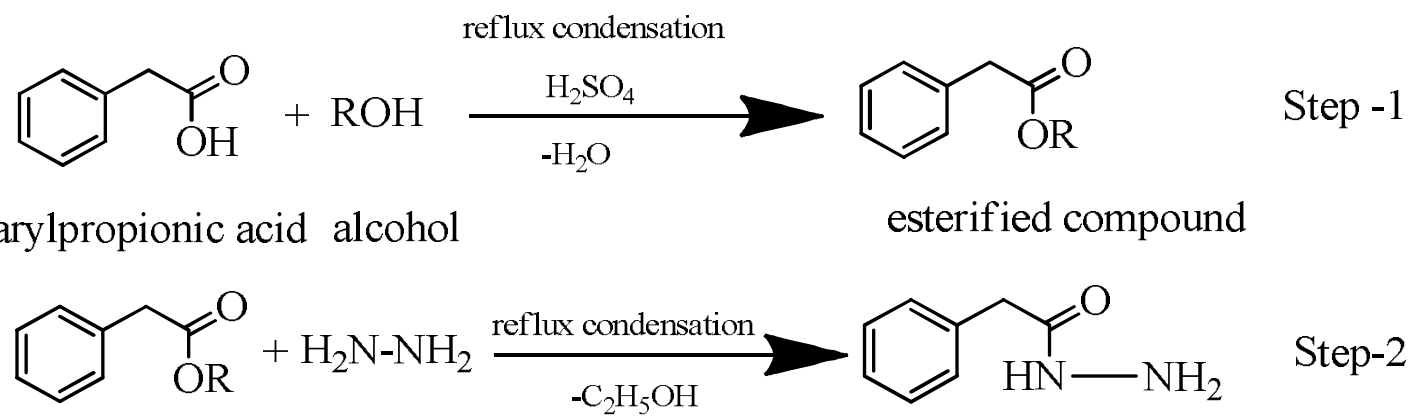

esterified compound hydrazine hydrate hydrazide compound

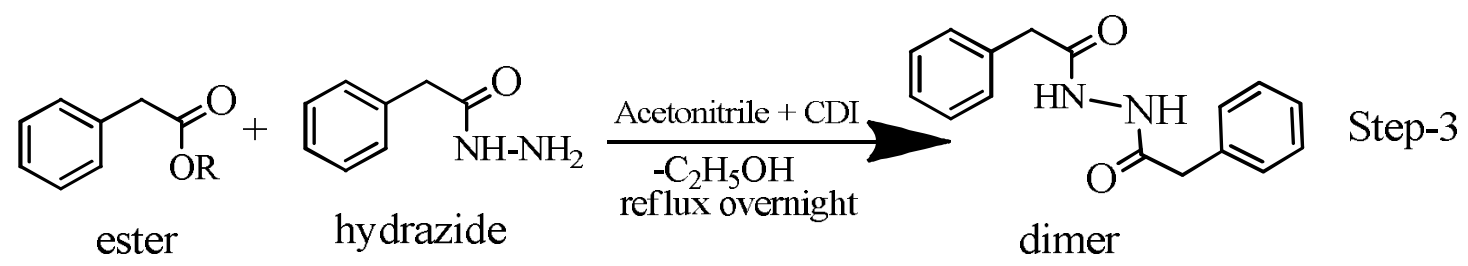

Scheme-I: Synthesis of dimers

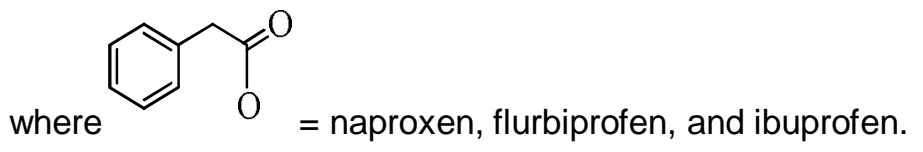

Table 1: Dimers of naproxen, flurbiprofen, and ibuprofen

Test
compound

15/Pharm), according to international guidelines for the handling of animals $[11,12]$.

\section{Acute toxicity test}

For the toxicity study, 18 mice were distributed randomly into three groups, $n=6$ each. Groups were treated with 50,100 , and $500 \mathrm{mg} / \mathrm{kg}$ body weight of the test compounds intraperitoneally (ip) through injection. The animals were observed for $6 \mathrm{~h}$ for any behavioural changes; 
mortality rates were determined at $24 \mathrm{~h}$ after administration of the test compounds [13].

\section{Anti-inflammatory activity (carrageenan- induced paw oedema) test}

This test was performed on 30 mice distributed randomly into five groups, $n=6$ each. Inflammation was induced by injecting $0.1 \mathrm{~mL}$ of $1 \%$ carrageenan solution into the plantar surface of the mouse hind paw [14]. Test groups I, II, and III were treated with 10,20 , and $30 \mathrm{mg} / \mathrm{kg}$ of the test compound, respectively. Group IV (control) was treated with normal saline $(1 \mathrm{~mL} / \mathrm{kg})$ while group V (reference standard) was treated with ketoprofen $(10 \mathrm{mg} / \mathrm{kg}), 30 \mathrm{~min}$ before carrageenan injection. The paw volume was measured at $0,1,2,3,4$, and $5 \mathrm{~h}$ using a digital plethysmometer. The difference between the readings at time $0 \mathrm{~h}$ and the different time points was taken as the degree of oedema, quantified as

$\%$ Inhibition $=(\alpha-\beta) / \alpha \times 100$

where $\alpha$ and $\beta$ indicate the increase in paw volume of control and drug-treated animals, respectively.

\section{Evaluation of anti-nociceptive activity}

\section{Acetic acid-induced writhing test in mice}

Mice were distributed into five groups [groups I, II, III, IV (control), and V (reference standard)], n = 6 each; at levels of 10,20 , and $30 \mathrm{mg} / \mathrm{kg}$ body weight ip, doses of the test compounds were administered to the animals of the first three groups I-III, respectively. The animals of group IV received normal saline $(10 \mathrm{~mL} / \mathrm{kg}$ body weight, ip) while those of group $\mathrm{V}$ were treated with diclofenac at a dose of $10 \mathrm{mg} / \mathrm{kg}$ body weight, ip. After an interval of $30 \mathrm{~min}$ after treatment, all groups were treated with $0.6 \%$ acetic acid at $10 \mathrm{~mL} / \mathrm{kg}$ body weight, ip [15]. The mice were then placed in individual cages and the numbers of writhes were counted for each mouse for a period of $30 \mathrm{~min}$, with a 5-min latency period.

\section{Hot plate (thermal) test in mice}

Mice weighing 18-22 $\mathrm{g}$ of both genders were used. As described in a reported protocol, animals habituated to the laboratory environment for $2 \mathrm{~h}$ were distributed into five groups, $n=6$ each. Test groups I, II, and III were treated with 10,20 , and $30 \mathrm{mg} / \mathrm{kg} / \mathrm{ip}$, respectively, of the test compound; group IV was treated with normal saline $(10 \mathrm{~mL} / \mathrm{kg}$, ip); and group $\mathrm{V}$ with tramadol at $5 \mathrm{mg} / \mathrm{kg}$, ip. The animals were subjected to the hot plate test after 30- and 60-min intervals; the hot plate was maintained at a temperature of $54.0 \pm 0.1^{\circ} \mathrm{C}$. The latency time (s), i.e., the reaction to the hot plate, was recorded by noting the reaction of the experimental animal, licking, flicking of the hind limb, or jumping from the cylinder [16]. The cut-off time was fixed at $30 \mathrm{~s}$ for the animal's reaction to avoid tissue damage due to prolonged exposure to the hot plate. Antinociception was determined using the formula:

$\%$ Anti-nociception $=\left(\frac{t-r}{g-c}\right) \times 100 \ldots \ldots(2)$

where $t$ is the test latency, $c$ is the control latency, and $s$ is the cut-off time.

\section{Anti-pyretic study (Brewer's yeast-induced pyrexia test)}

Mice of either sex, weighing $25-30 \mathrm{~g}$, were used. As described in a reported protocol, before the experimental procedure, the animals fasted overnight but with free access to water. The animals were distributed into five groups, $n=6$ each. Doses of 10,20 , and $30 \mathrm{mg} / \mathrm{kg}$ of the test compound were administered to the animals of the first three groups (groups I-III), respectively. Animals of group IV were treated with normal saline $(10 \mathrm{~mL} / \mathrm{kg})$, and those of group $\mathrm{V}$ were treated with paracetamol $(150 \mathrm{mg} / \mathrm{kg})$. Brewer's yeast solution $(20 \%)$ was administered subcutaneously (sc) below the nape of neck in the back of the mice (10 mL/kg body weight) to induce hyperpyrexia in the experimental animals in all groups [17]. Twenty-four hours after the injection, changes in rectal temperature were recorded by inserting an oil-lubricated digital thermometer into their rectums at 1, 2, 3, 4, and $5 \mathrm{~h}$. Only those mice whose rectal temperatures had increased by at least $0.3-0.5{ }^{\circ} \mathrm{C}$ were selected for further test procedures.

\section{Statistical analysis}

For statistical analyses, GraphPad Prism (ver. 5.01) software was used. Data pertaining to pharmacological evaluation were analysed by applying one-way analysis of variance (ANOVA) followed by Dunnett's post hoc analysis. $P$ $<0.001$ was considered to be highly significant while $p<0.05$ was considered statistically significant in this study.

\section{Molecular docking simulation analysis}

AutoDock (ver. 4.0.1.) software was used for docking simulation analyses. A rigid-protein-andflexible-ligand standard docking procedure was performed with the AutoDock Tools, using a Lamarckian generic logarithm. A three- 
dimensional $60 \times 60 \times 60$ point grid was built, centred on the centre of the M loop of COX2 (PDB ID: 3PGH). An energy map was calculated using a grid spacing of $0.375 \AA$ and a distancedependent function of the dielectric constant, while default settings were used for the other parameters. After completion of the docking, the most favourable free binding energies were selected as the resulting ligand-protein interactions [18]. Flurbiprofen was used as a reference and co-crystallised ligand was used to assess binding mode accuracy and test compound affinity [19].

\section{RESULTS}

\section{Chemistry of the synthesised dimers}

Test compound (TC)-I: $\mathrm{mp}=$ semisolid; yield: $0.389 \mathrm{~g}$ (82.67\%): IR (KBr): $v_{\max }$ 3,527.6, $3,144.7,2,826.5, \quad 1,964.4, \quad 1,807.2, \quad 1,624.9$, 1,483.2, 1,414.7, 1,341.4, 1,133.1, 939.3, 914.2, 769.5, 701.1 $\mathrm{cm}^{-1} ;{ }^{1} \mathrm{H}$ NMR $(400 \mathrm{MHz}$, chloroform): $\delta 10.08$ (s, 1H), 7.77-7.66 (m, 3H), 7.55-7.38 (m, 7H), 7.36-7.27 (m, J = $12.0 \mathrm{~Hz}$, $2 \mathrm{H}), 7.23(\mathrm{t}, \mathrm{J}=1.2,1.6 \mathrm{~Hz} 1 \mathrm{H}), 7.06(\mathrm{dd}, \mathrm{J}=$ 7.6, 1.6, 1H), $3.81(\mathrm{~s}, 3 \mathrm{H}), 3.52(\mathrm{~m}, 2 \mathrm{H}), 1.34(\mathrm{~d}$, $1 \mathrm{H}), \quad 1.28$ (d, 1H). El MS: $\mathrm{m} / \mathrm{z}$ (relative abundance \%): $472\left(\mathrm{M}^{+}, 5.7\right), 360$ (7.3), 300 (28.3), 256 (33.2), 220 (100) 156 (60), 136 (30), 80 (10); elemental analysis for $\mathrm{C}_{29} \mathrm{H}_{27} \mathrm{FN}_{2} \mathrm{O}_{3}$ : C, 72.91; H, 5.28; F, 5.24; N, 7.73; O, 8.83.

Test compound (TC)-Il: $\mathrm{mp}=$ liquid; yield: 0.28 g (67.4\%): IR (KBr): $v_{\max } 3,160,2,955,1,781$, $1,624,1,512,1,459,1,208,924,847,734 \mathrm{~cm}^{-1}$; $1 \mathrm{H}$ NMR (300 MHz, DMSO- $\left.d_{6}\right): \delta 12.16(\mathrm{~s}, 2 \mathrm{H}$, $\mathrm{NH}), 7.14(\mathrm{~m}, 8 \mathrm{H}, \mathrm{H}-2 / 3 / 5 / 6), 4.07$ (q, 2H, CH), $2.39\left(\mathrm{~d}, 4 \mathrm{H}, \mathrm{CH}_{2}\right), 1.78(\mathrm{~m}, 2 \mathrm{H}, \mathrm{CH}), 1.47(\mathrm{~d}, 6 \mathrm{H}$, $\mathrm{CH}_{3}$ ), 0.83 (d, $12 \mathrm{H}, \mathrm{CH}_{3}$ ); El MS: $\mathrm{m} / \mathrm{z}$ (relative abundance \%): 246 (50.9), 203 (100), 118 (49.7), 91 (26.4), 43 (7.5); elemental analysis for $\mathrm{C}_{26} \mathrm{H}_{36} \mathrm{~N}_{2} \mathrm{O}_{2}$ : C, 76.43; $\mathrm{H}, 8.88 ; \mathrm{N}, 6.86$; found: $\mathrm{C}$, 75.98; H, 8.62; N, 6.90.

Test compound (TC)-III: MP: $77.35^{\circ} \mathrm{C}$; yield: $0.24 \mathrm{~g}, 53.73 \%$ : IR (KBr): $v_{\max } 3,143,1,770$, 1,604, 1,504, 1,229, 1,031, 960, 820, 745, 719 $\mathrm{cm}^{-1} ;{ }^{1} \mathrm{H}$ NMR (300 MHz, DMSO- $\left.d_{6}\right): \delta 12.16(\mathrm{~s}$, $2 \mathrm{H}, \mathrm{NH}), 7.80(\mathrm{~m}, 4 \mathrm{H}, \mathrm{H}-4 / 8), 7.73\left(\mathrm{~d}, j_{1,3}=0.5\right.$ $\mathrm{Hz}, 2 \mathrm{H}, \mathrm{H}-1), 7.37$ (dd, $j_{3,4}=8.5 \mathrm{~Hz}, j_{3,1}=2.0 \mathrm{~Hz}$, $2 \mathrm{H}, \mathrm{H}-3), 7.30\left(\mathrm{~d}, j_{5,7}=2.5 \mathrm{~Hz}, 2 \mathrm{H}, \mathrm{H}-5\right), 7.16$ (dd, $j_{7,8}=9.0 \mathrm{~Hz}, j_{7,5}=2.5 \mathrm{~Hz}, 2 \mathrm{H}, \mathrm{H}-7$ ), 4,25 (q, $2 \mathrm{H}, \mathrm{CH}), 3.30\left(\mathrm{~s}, 6 \mathrm{H}, \mathrm{OCH}_{3}\right), 1.56\left(\mathrm{~d}, 6 \mathrm{H}, \mathrm{CH}_{3}\right)$; El MS: $m / z$ (relative abundance \%): $456\left(\mathrm{M}^{+}\right.$, 3.4), 438 (58.1), 270 (33.3), 212 (57), 185 (100); elemental analysis for $\mathrm{C}_{28} \mathrm{H}_{28} \mathrm{~N}_{2} \mathrm{O}_{4}: \mathrm{C}, 73.66 ; \mathrm{H}$, 6.18; N, 6.14; found: C, 73.68; H, 5.17; N, 6.19.
Test compound (TC)-IV: $\mathrm{mp}: 185.5^{\circ} \mathrm{C}$, Yield: $0.38 \mathrm{~g}, 79.5 \%$ : IR (KBr): $v_{\max } 3,145,2,826,1,806$, 1,762, 1,624, 1,483, 1,414, 1,341, 939, $769 \mathrm{~cm}^{-1}$; ${ }^{1} \mathrm{H}$ NMR (300 MHz, DMSO- $\left.d_{6}\right): \delta 11.32(\mathrm{~s}, 2 \mathrm{H}$, $\mathrm{NH}), 7.44\left(\mathrm{~m}, 12 \mathrm{H}, \mathrm{H}-5 / 6 / 2^{\prime} / 3^{\prime} / 5^{\prime} / 6^{\prime}\right), 7.25(\mathrm{~m}$, $4 \mathrm{H}, \mathrm{H}-2 / 4^{\prime}$ ), 4.23 (q, 2H, CH), 1.53 (d, 6H, $\mathrm{CH}_{3}$ ); EI MS: $m / z$ (relative abundance \%): $\left(\mathrm{M}^{+}\right.$, absent), 466 (3.9), 284 (100), 269 (63.6), 225 (27.7), 43 (43.4); elemental analysis for $\mathrm{C}_{30} \mathrm{H}_{26} \mathrm{~F}_{2} \mathrm{~N}_{2} \mathrm{O}_{2}$ : C, 74.36; H, 5.41; N, 5.78; found: C, 74.28; H, 5.82; N, 5.84 .

\section{Acute toxicity}

No acute toxicity was observed over the $24 \mathrm{~h}$ following dosing of 50,100 , or $150 \mathrm{mg} / \mathrm{kg}$ body weight of any test compound.

\section{Anti-inflammatory activity}

Anti-inflammatory activity data were analysed using one-way ANOVA followed by Dunnett's post hoc analysis. Figure 1 shows that all test compounds had statistically significant antiinflammatory effects $\left({ }^{* * *} p<0.0001\right)$ at the given doses with reference to normal saline $(10 \mathrm{~mL} / \mathrm{kg})$ as a control and ketoprofen $10 \mathrm{mg} / \mathrm{kg}$ as a reference standard. Doses of the four compounds were selected on the basis of average doses of the lead drug molecules used.

\section{Anti-nociceptive activity}

The hot plate test was negative for all of the test compounds, indicating that the test compounds had no central analgesic activity. To avoid a congested presentation, data for only the $30 \mathrm{mg}$ doses are reported. The overall result of this test was negative.

Data for the acetic acid-induced writing test indicated that the test compounds (TC-I, -II -III, and -IV) were active versus the normal saline 10 $\mathrm{mL} / \mathrm{kg}$ control and diclofenac $10 \mathrm{mg} / \mathrm{kg}$ reference standard $\left({ }^{* *} p<0.001\right)$, indicating a clear doseresponse relationship (Figure 2).

\section{Anti-pyretic activity}

Brewer's yeast-induced pyrexia test results showed that the antipyretic activity of the four compounds was significant $(p<0.001)$ at all of the doses tested versus the control (normal saline $10 \mathrm{~mL} / \mathrm{kg}$ ) and paracetamol $(150 \mathrm{mg} / \mathrm{kg}$ body weight) reference standard (Figure 4).

\section{Molecular docking results}

Molecular docking simulates and determines the best-fit orientation of the ligand (drug) on the 


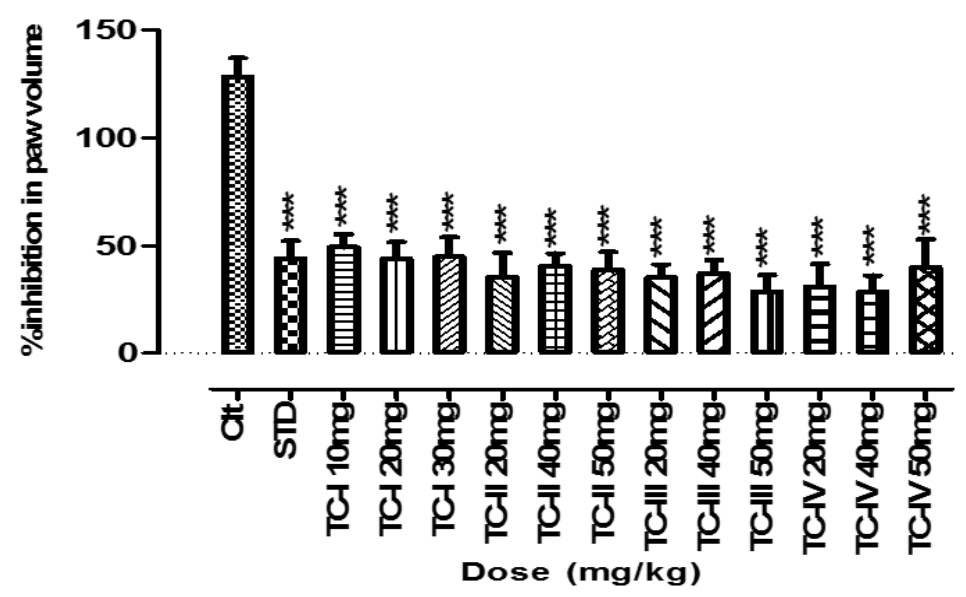

Figure 1: Anti-inflammatory activity of TC-I, -II, -III, and -IV, and control (normal saline $10 \mathrm{~mL} / \mathrm{kg}$ ) and reference standard (ketoprofen $10 \mathrm{mg} / \mathrm{kg}$ ). Error bars indicate mean \pm SEM (of \% inhibition of oedema in the paws of experimental animals, $n=6$ ). The anti-inflammatory effects of the test compounds were significant at all three doses used $\left.{ }^{* * *} p<0.001\right)$

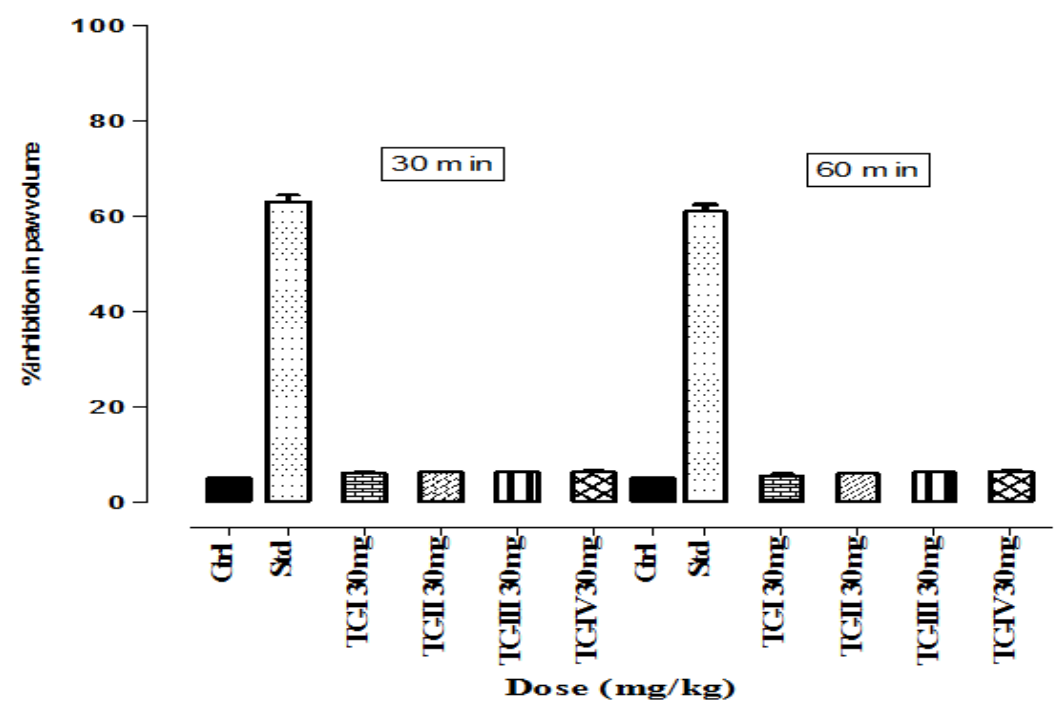

Figure 2: Analgesic sctivity of TC-I, -II, -III, and TC-IV, at $30 \mathrm{mg} / \mathrm{kg}$, and control (normal saline $10 \mathrm{~mL} / \mathrm{kg}$ ) and the reference standard tramadol $(5 \mathrm{mg} / \mathrm{kg}$ ). Error bars indicate mean \pm SEM (of \% inhibition, $n=6$ )

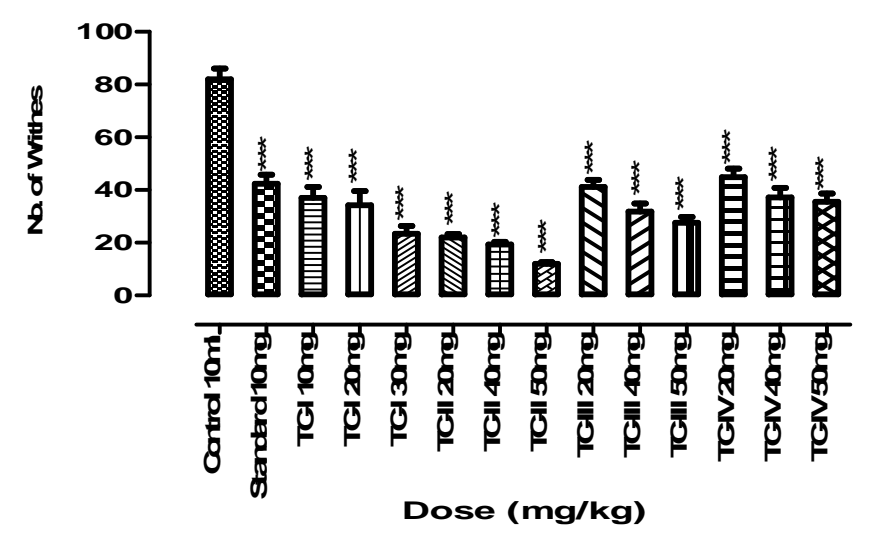

Figure 3. Summarised comparison showing anti-nociceptive activity of the standard (diclofenac $10 \mathrm{mg} / \mathrm{kg}$ ) and TC-I to IV, and their respective doses $(\mathrm{mg} / \mathrm{kg}$ ) versus the control (normal saline $10 \mathrm{~mL} / \mathrm{kg}$ ). Bars indicate means \pm SEM of number of writhes in each group $(n=6)$. The effects were significant for the four compounds $\left({ }^{* * *} p<0.001\right)$ 


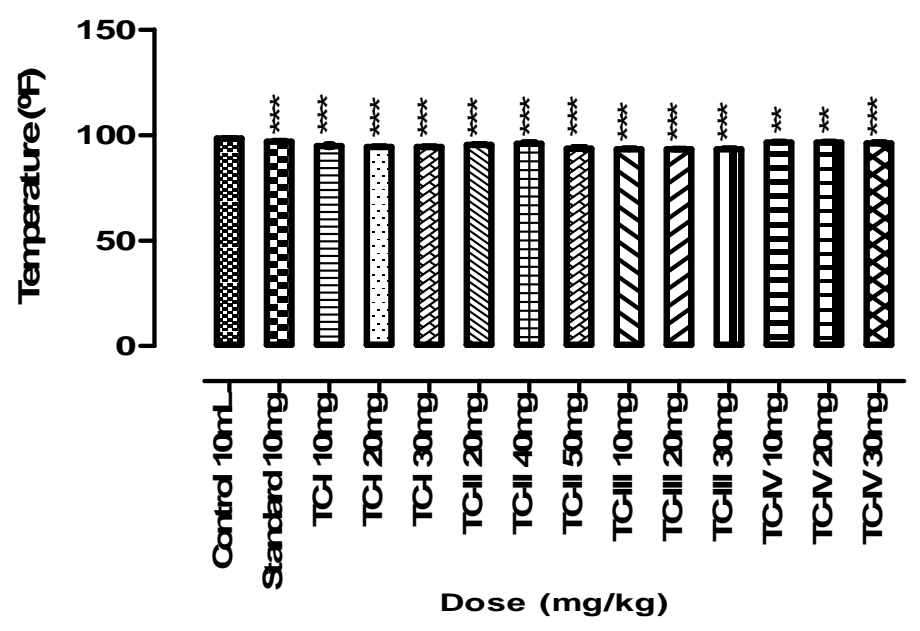

Figure 4: Antipyretic activity of the standard (paracetamol $150 \mathrm{mg} / \mathrm{kg}$ ), test compounds TC-I to IV and control (normal saline, $10 \mathrm{~mL} / \mathrm{kg}$ ); mean \pm SEM $(n=6)$. The effects of all four compounds were significant $\left.{ }^{* * *} p<0.001\right)$ at the respective doses.

basis of binding scores (energies), at the specific binding site of the receptor protein, which can authenticate or suggest pharmacological activity and drug design rationales, with reference to the receptor protein studied [20]. COX1, a constitutively expressed enzyme, catalyses primarily the production of prostaglandins that regulate homeostasis, platelet activity, and gastric and renal function. COX-2, is a constitutive and inducible enzyme that catalyses predominantly the production of proinflammatory prostaglandins [21].

Computational modelling tests with the TCs revealed that the 'best' scoring conformations (energies) of the TCs (I, II, III, and IV) were much higher than that of flurbiprofen, the reference ligand (Table 2, Figures. 5-9). Superimposition of the most favourable conformations of the test compounds and of the reference ligand (Figure 10) showed that they were accommodated well within the COX2 active site pocket.

Table 2: Highest docking scores of the TCs and reference ligand

\begin{tabular}{lc}
\hline Compound & Docking score $(\mathbf{k c a l} / \mathbf{m o l})$ \\
\hline Flurbiprofen & -94.929 \\
TC-I & -116.247 \\
TC-II & -128.873 \\
TC-III & -144.211 \\
TC-IV & -136.044 \\
\hline
\end{tabular}

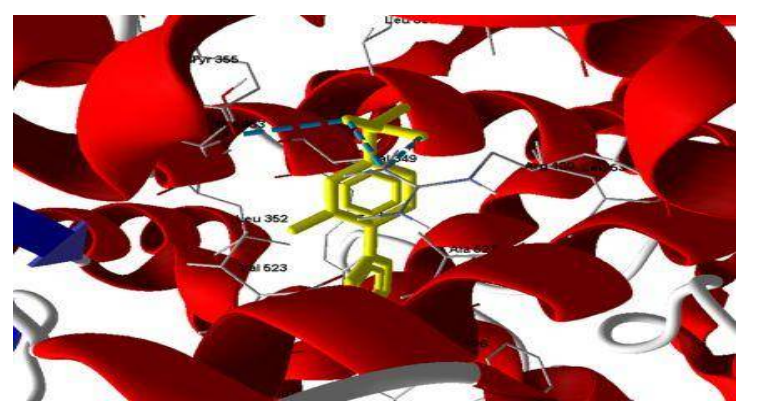

Figure 5: Docking of flurbiprofen (reference ligand) in the active site of the COX2 enzyme

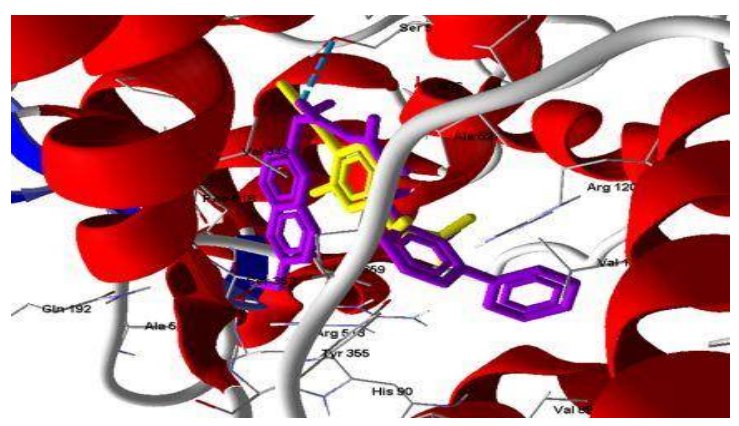

Figure 6: Docking of TC-I in the active site of the cox2 enzyme

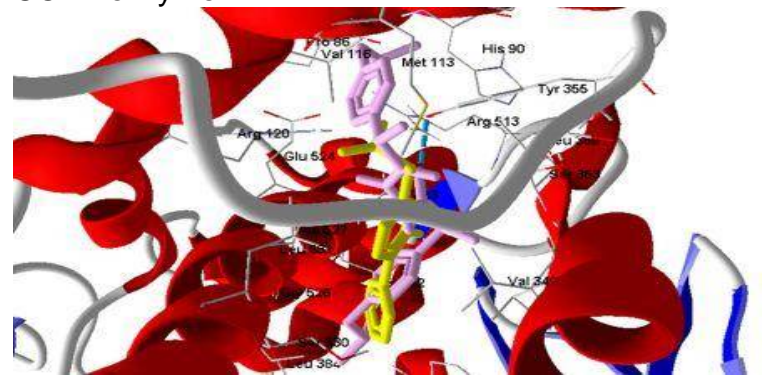

Figure 7: Docking of TC-II in the active site of the COX2 enzyme 




Figure 8: Docking of TC-III in the active site of the cOX2 enzyme

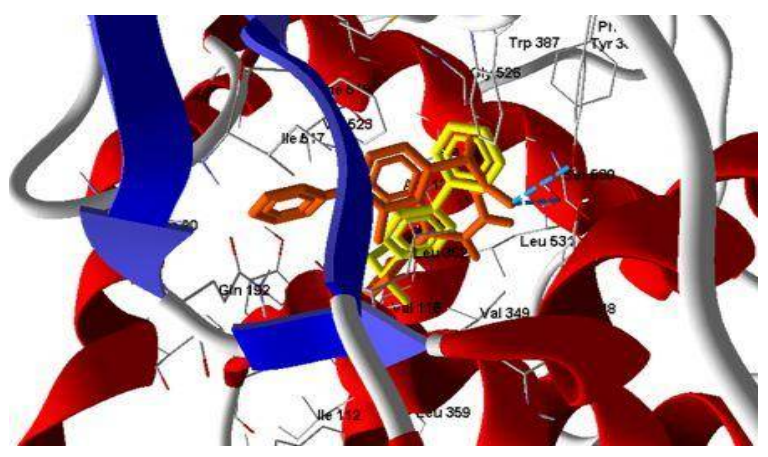

Figure 9: Docking of TC-IV in the active site of the cOX2 enzyme

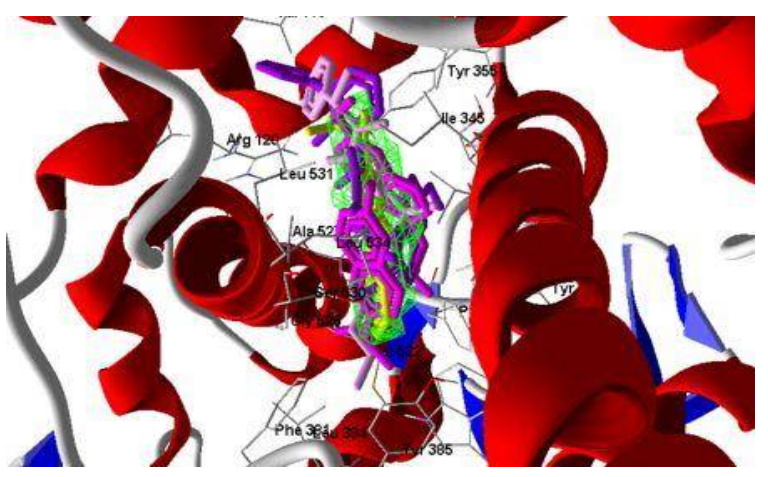

Figure 10: Superimposition of the most favourable conformations of test compounds TC-I (red), TC-II (green), TC-III (blue), TC-IV (brownish-orange), and the reference ligand, flurbiprofen (yellow), docked in the binding pocket of the COX-2 enzyme

\section{DISCUSSION}

Despite remarkable advances in pharmaceutical chemistry, inflammatory conditions remain major challenges in terms of both curative and symptomatic treatments. More effective and safer COX inhibitors are required. In our present study featuring pharmacological and computational analysis, we discovered an interesting aspect of COX targeting. What we term "dimerised COX inhibitors" are more potent than are lead molecules. All test compounds exhibited highly significant anti-inflammatory and peripheral analgesic activities, and such activities were dose-dependent. The effectiveness of an
NSIAD is related to the rapidity and efficacy of access through the narrow COX channel created by Arg-120, Tyr-355, and Glu-524 [22]. Our in vivo tests clearly showed that COX2 was effectively inhibited by dimerised analogues of selective lead molecules that were larger in size than unitary lead molecules. The active site of COX2, which encompasses the Val-523 amino acid residue, permits secondary, internal hydrophobic extension of the binding site to accommodate larger molecules [23]. We suggest that this explains the responses to our test compounds; this suggestion is supported by our molecular docking analysis. The docking scores of the test compounds (Table 2), and superimposition of the most favourable confirmations [24] (Fig. 10), both support this hypothesis. Arylpropionic acid COX inhibitors bind in one of two reported poses within the COX binding pocket: (i) in a way that the carboxylate moiety is bound to the edifice site residues Arg120 and Tyr-355, such as flurbiprofen [25, 26], or (ii) whereby the carboxylate moiety binds to the side chains of Tyr-385 and/or Ser-530 residues in an upturned fashion, such as diclofenac [20]. The 'best' conformations of the test compounds showed that TC-I was bound via a hydrogen bond with Ser-530, TC-II with Try-355, TC-III had only hydrophobic interactions (Val-116, Leu-359, Leu-351, Leu-354, Val-344, Leu-352, Phe-518, Leu-384, Val-523, and Met-522), also reported as a 'second anchoring site' by Jelena [23]. In contrast, TC-IV featured a hydrogen bond between Try-385 and Ser-530. Computational studies firmly supported the data of the in vivo experiments. It appears that the dimerisation concept may be used to identify useful lead compounds, opening a novel window into the management of overwhelming inflammatory disorders. These fascinating detailed findings warrant further mechanistic studies, with a focus on sequential virtual design, chemical modification, and 3DQSAR evaluation. Marketable therapies may result.

\section{CONCLUSION}

The in vivo results demonstrate that dimerisation, homo- or hetero-, within the selected lead drug molecules increased pharmacological activities (anti-inflammatory, analgesic and antipyretic). Thus, all four dimers should be assessed further as new candidate molecules for the treatment of inflammatory conditions.

\section{DECLARATIONS}

\section{Acknowledgement}

This research was self-financed by SMA Halimi. 
The authors wish to thank PolyFine ChemPharma (Pvt.) Ltd., Hayatabad Industrial Estate, Peshawar, Khyber Pakhtunkhwa, Pakistan for providing the ibuprofen, flurbiprofen, and naproxen used in the study.

\section{Conflict of Interest}

No conflict of interest associated with this work.

\section{Contribution of Authors}

The authors declare that this work was done by the authors named in this article and all liabilities pertaining to claims relating to the content of this article will be borne by them.

\section{Open Access}

This is an Open Access article that uses a funding model which does not charge readers or their institutions for access and distributed under the terms of the Creative Commons Attribution License (http://creativecommons.org/licenses/by 14.0) and the Budapest Open Access Initiative (http://www.budapestopenaccessinitiative.org/rea d), which permit unrestricted use, distribution, and reproduction in any medium, provided the original work is properly credited.

\section{REFERENCES}

1. Ray WA, Varas-Lorenzo C, Chung CP, Castellsague J, Murray KT, Stein $C M$, Daugherty JR, Arbogast PG, García-Rodríguez LA. Cardiovascular risks of nonsteroidal anti-inflammatory drugs in patients after hospitalization for serious coronary heart disease. Circ. Cardiovasc. Qual. Outcomes. 2009; 2: 155-163.

2. Van Hecken A, Schwartz JI, Depré M, De Lepeleire I, Dallob A, Tanaka W, Wynants K, Buntinx A, Arnout J, Wong PH, Ebel DL, Gertz BJ, De Schepper PJ. Comparative inhibitory activity of rofecoxib, meloxicam, diclofenac, ibuprofen, and naproxen on COX-2 versus COX-1 in healthy volunteers. J. Clin. Pharmacol. 2000 Oct.; 40(10):1109-20.

3. Wlodawer, A. Rational approaches to AIDS drug design through structural biology. Annu. Rev. Med. 2002; 53 595-614.

4. Schneider G, Fechner U. Computer-based de novo design of drug-like molecules. Nat. Rev. Drug. Discov. 2005; 4(8): 649-663.

5. Kubinyi H. In Success stories of Computer-aided Design, Ed: by S. Ekins. Computer applications in pharmaceutical research and development. Johan Wiley \& Sons Inc: USA, 2006, pp 377.

6. Harrington PJ, Lodewijk E. Twenty years of naproxen technology. Org. Process Res. \& Devel. 1997; 1(1): 7276
7. Brogden RN, Heel RC, Speight $M$ and Avery GS. Flurbiprofen: a review of its pharmacological properties and therapeutic use in rheumatic diseases. Drugs. 1979; 18(6): 417-438.

8. Halford GM, Lordkipanidze M, Watsan SP. 50th Anniversary of the discovery of ibuprofen: an interview with Dr Stewart Adams. Platelets. 2012; 23(6): 415-422.

9. Reid EE. Esterification A review of the recent past and a look towards the future. Indust. \& Eng. Chem. 1937; 29(12): 1344-1350.

10. Khan KM, Rasheed M, Zia-Ullah, Hayat S, Kaukab F, Choudhary MI, Atta-ur-Rahman, Perveen S. Synthesis and in vitro leishmanicidal activity of some hydrazides and their analogues. Bioorg. Med. Chem. 2003; 11(7):1381-7.

11. Guidelines made under Animal (Scientific and Procedure) Act 1986 (https://www.gov.uk/guidance/research-andtesting-using-animals), adopted by the Ethical Committee.

12. Directives of 2010/63/EU on the protection of animals used for scientific purposes (http://eurlex.europa.eu/ LexUriServ/LexUriServ.do?uri=OJ:L:2010:276:0033:007 $9: E N)$.

13. Bruce RD. An up-and-down procedure for acute toxicity testing. Toxicol. Sci. 1985; 5(1): 151-157.

14. Winter, CA, Riselay, EA, Nuss, GW. Carrageenaninduced oedema in the hind paw of the rats as an assay for anti-inflammatory drugs. Proc. Soc. Exp. Biol. Med. 1962; 111: 544-547.

15. Koster RR, Anderson M, De Beer EJ (1959). Acetic acid for analgesic screening. Federation proceedings. 1959; 18: 412.

16. Eddy, NB, Leimbach, D. Synthetic analgesics. II. Dithienylbutenyl- and dithienylbutylamines. J. Pharmacol. Exp. Ther. 1953; 107 (3): 385-393. PMID 13035677.

17. Bottcher I, Schweizer A, Glatt M, Werner H. Drugs Experi. Clin. Res. 1987; 13: 237-45.

18. Khan I, Nisar M, Ahmad M. Molecular simulations of Taxawallin I inside classical taxol binding site of $\beta$ tubulin. Fitoterapia. 2011; 82: 276-281.

19. Ali G, Subhan F, Wadood A. Pharmacological evaluation, molecular docking and dynamics simulation studies of salicyl alcohol nitrogen containing derivatives. Afr. J. Pharm. Pharmacol. 2013; 7(11): 585-596.

20. Rowlinson SW, Kiefer JR, Prusakiewicz JJ, Pawlitz JL, Kozak KR, Kalgutkar AS, Stallings WC, Kurumbail RG, Marnett LJ. A novel mechanism of cyclooxygenase-2 inhibition involving interactions with Ser-530 and Tyr385. J. Biol. Chem. 2003; 278: 45763-45769.

21. Kathleen MK, Arduino AM, John OM. Defining the COX inhibitor selectivity of NSAIDs: implications for understanding toxicity. Expert. Rev. Clin. Pharmacol. 2010; 3(6): 769-776.

22. Selinsky BS, Gupta K, Sharkey CT, Loll PJ. Structural analysis of NSAID binding by prostaglandin H2 synthase: time-dependent and time independent 
Halimi et al

inhibitors elicit identical enzyme conformations. Biochemistry. 2001; 40: 5172-5180.

23. Warner TD, Mitchell JA. COXs: New forms, new inhibitors, and lessons from the clinic. FASEB J. 2004; 18: 790-804.

24. Jelena SS, Sanda PD, Bojan D, Marković Marina TM, Sote MV, Ivan OJ. Docking studies and $\alpha$-substitution effects on the anti-inflammatory activity of $\beta$-hydroxy- $\beta$ arylpropanoic acids. Molecules. 2011; 16(8): 6645-6655.
25. Kurumbail RG, Stevens AM, Gierse JK, McDonald JJ, Stegeman RA, Pak JY, Gildehaus D, Miyashiro JM, Penning TD, Seibert K, Isakson PC, Stallings WC. Structure basis for selective inhibition of cyclooxygenase - 2 by anti-inflammatory agents. Nature. 1996; 384: 644-648.

26. Picot D, Loll PJ, Garavito RM. The X-ray crystal structure of the membrane protein prostaglandin $\mathrm{H} 2$ synthase-1. Nature. 1994; 367, 243-249 [PubMed: 8121489]. 